2 Kapoor WN. Syncope. N Engl J Med 2000;343:1856-62.

White CM, Tsikouris JP. A review of pathophysiology and therapy of patients with vasovagal syncope. Pharmacotherapy 2000;20:158-65.

4 Brignole M, Alboni P, Benditt D, Bergfeldt L, Blanc JJ, Bloch Thomsen PE, et al for the Task Force on Syncope, European Society of Cardiology Guidelines on management (diagnosis and treatment) of syncope. Eu Heart J 2001;22:1256-306.

5 Kenny RA. Neurally mediated syncope. Clin Geriatr Med 2002;18:191-210.

6 Benditt DG, Ferguson DW, Grubb BP, Kapoor WN, Kugler J, Lerman BB, et al. ACC expert consensus document: tilt table testing for assessing syncope. J Am Coll Cardiol 1996;28:263-75.

7 Fogoros RN. Practical cardiac diagnosis: electrophysiologic testing. 3rd ed. Malden, MA: Blackwell Publishing, 1999

8 Krediet CT, van Dijk N, Linzer M, van Lieshout JJ, Wieling W. Management of vasovagal syncope: controlling or aborting faints by leg crossing and muscle tensing. Circulation 2002;106:1684-9

9 Lu CC, Diedrich A, Tung CS, Paranjape SY, Harris PA, Byrne DW, et al Water ingestion as prophylaxis against syncope. Circulation 2003;108:2660-5

10 Zaqqa M, Massumi A. Neurally mediated syncope. Tex Heart Institute J 2000;27:268-72.

11 Nair N, Padder FA, Kantharia BK. Pathophysiology and management of neurocardiogenic syncope. Am J Managed Care 2003;9:327-34

12 Sutton R, Petersen ME. The clinical spectrum of neurocardiogenic syncope. J Cardiovasc Electrophysiol 1995;6:569-76.

13 Fyncope. J Cardiovasc Electrophysiol 1995;6.569-76. and vasovagal syncope. Heart Dis 2003;5:49-64.

14 Gregoratos G, Cheitlin M, Conill A, Epstein AE, Fellows C, Ferguson TB $\mathrm{Jr}$, et al. ACC/AHA guidelines for implantation of cardiac pacemakers and antiarrhythmia devices: executive summary-a report of the American College of Cardiology/American Heart Association task force on practice guidelines (committee on pacemaker implantation). Circulation 1998;97:1325-35

15 O'Mahony D. Pathophysiology of carotid sinus hypersensitivity in elderly patients. Lancet 1995;346:950-2.

16 Madrid AH, Ortega J, Rebollo JG, Manzano JG, Segovia JG, Sanchez A, et al. Lack of efficacy of atenolol for the prevention of neurally mediated syncope in a highly symptomatic population: a prospective, double-blind, rancope in a highly symptomatic population: a prospective, double-blind, r
domized and placebo-controlled study. $\mathrm{Am}$ Coll Cardiol 2001;37:544-9.

17 Flevari P, Livanis EG, Theodorakis GN, Zarvalis E, Mesiskli T, Kremastinos DT. Vasovagal syncope: a prospective, randomized, crossover evaluation of the effect of propranolol, nadolol and placebo on syncope recurrence and patients' well-being. J Am Coll Cardiol 2002;40:499-504

18 Kaufmann H, Saadia D, Voustianiouk A. Midodrine in neurally mediated syncope: a double-blind, randomized, crossover study. Ann Neurol 2002;52:342-5

19 Perez-Lugones A, Schweikert R, Parra S, Sra J, Akhtar M, Jaeger F, et al. Usefulness of midodrine in patients with severely symptomatic neurocardiogenic syncope: a randomized control study.J Cardiovasc Electrophysiol diogenic syncope:

20 Ward CR, Gray JC, Gilroy JJ, Kenny RA. Midodrine: a role in the management of neurocardiogenic syncope. Heart 1998;79:45-9.

21 DiGirolamo E, Di Iorio C, Sabatini P, Leonzio L, Barbone C, Barsotti A Effects of paroxetine hydrochloride, a selective serotonin reuptake inhibitor, on refractory vasovagal syncope: a randomized, double-blind, placebo-controlled study. J Am Coll Cardiol 1999;33:1227-30.

22 Da Costa D, McIntosh S, Kenny RA. Benefits of fludrocortisone in the treatment of symptomatic vasodepressor carotid sinus syndrome. $B r$ Heart J 1993;69:308-10.

23 Scott WA, Pongiglione G, Bromberg BI, Schaffer MS, Deal BJ, Fish FA, et al. Randomized comparison of atenolol and fludrocortisone acetate in

\section{Additional educational resources}

Resources for healthcare professionals

Heart Rhythm Society (www.hrspatients.org/patients/signs_symptoms/ fainting/non-cardiovascular_syncope.asp) - describes neurocardiogenic syncope and its causes, diagnosis, and treatment

Brignole M, Alboni P, Benditt D, Bergfeldt L, Blanc JJ, Bloch Thomsen PE, et al for the European Society of Cardiology. Guidelines on management (diagnosis and treatment) of syncope. Eur Heart J 2001;22:1256-306 Brignole M, Alboni P, Benditt D, Bergfeldt L, Blanc JJ, Bloch Thomsen PE, et al. Task force on syncope, European Society of Cardiology: part 1-the initial evaluation of patients with syncope. Europace 2001;3:253-60

Brignole M, Alboni P, Benditt D, Bergfeldt L, Blanc JJ, Bloch Thomsen PE, et al. Task force on syncope, European Society of Cardiology: part 2-diagnostic tests and treatment: summary of recommendations. Europace 2001;3:261-8

Kapoor WN. Syncope. N Engl J Med 2000;343:1856-62

Benditt DG, Ferguson DW, Grubb BP, Kapoor WN, Kugler J, Lerman BB, et al. Tilt table testing for assessing syncope. J Am Coll Cardiol 1996;28:263-75

\section{Four key ongoing research studies}

Relationship of autonomic function to hypnotic susceptibility-a study to investigate the relation between susceptibility to hypnosis and regulation of the autonomic nervous system

Propranolol for syncope with sympathoadrenal imbalance-evaluating treatment with oral propranolol for a particular form of neurocardiogenic syncope characterised by a neuroendocrine pattern called sympathoadrenal imbalance

Clinical laboratory evaluation of chronic orthostatic intolerance- to identify and characterise distinct types of chronic orthostatic intolerance

Randomized study of midodrine, an adrenergic agonist, in patients with neurally mediated syncope-to determine the efficacy of midodrine, a selective $\alpha_{1}$ adrenergic agonist, in preventing neurally mediated syncope (For more detailed information, visit www.clinicaltrials.gov and enter "syncope" as search term)

the treatment of pediatric neurally mediated syncope Am J Cardiol 1995; 76:400-2.

24 Hussain RM, McIntosh SJ, Lawson J, Kenny RA. Fludrocortisone in the treatment of hypotensive disorders in the elderly. Heart 1996;76:507-9.

25 Connolly SJ, Sheldon R, Roberts RS, Gent M. The North American vasovagal pacemaker study (VPS): a randomized trial of permanent cardiac pacing for the prevention of vasovagal syncope. J Am Coll Cardiol 1999;33:16-20.

(Accepted 4 June 2004)

\title{
The other side of medicine
}

Going to work in the week before Christmas, I was reminded of an event in my school days. As 11 year olds, we were asked to write a piece of prose about Christmas. Understandably, we all set to work writing about food, presents, and festivities. Well, not quite all: one of my classmates surprised us all, and left an impression on some of us, by writing an account titled "The other side of Christmas," in which he described the Christmas experience for a homeless person. Well written, but not pleasant reading.

I am currently working as a senior house officer in paediatrics, and I have been taken aback by the generosity of the many individuals and organisations who have given their time and gifts to the children who will spend their Christmas on an acute paediatric ward. We have had visits from the local newspaper and local B-list celebrities, and there have been, quite literally, van loads of gifts arriving daily.

The ward office is now a storeroom, and the gifts piled high are remarkable, including televisions, video players, and hi fi systems. There are numerous video games and CDs, and a six foot long game of table football. There are boxes of sweets, cuddly toys, and craftwork materials. Four lucky children look set to receive a personal CD player, though it has not yet been decided how all these wonderful gifts will be distributed. How do you decide who should get the adult size mountain bike that was wheeled in?

All of this is a far cry from the build up to Christmas that I witnessed last year. Then, as a senior house officer in psychiatry, I saw the staff club together to try to buy some gifts for the men and women who would be spending Christmas as patients on the ward. There were no local benefactors and no rush of people making donations for these patients. There was certainly no visit from the local football team, who we are expecting on the paediatric ward this week. In the end, we pooled enough money to buy the men a tub of talcum powder and the women some basic toiletries.

We are really grateful for the generosity that has been shown towards the children who are unwell, but I cannot help but think of patients with mental health problems, who really are the other side of medicine.

Edward C A Barrett senior house officer, Queen's Hospital, Birmingham 